\title{
Aquatic macrophytes as indicators of water quality in subtropical shallow lakes, Southern Brazil
}

\author{
Macrófitas aquáticas como indicadores da qualidade da água \\ em pequenos lagos rasos subtropicais, Sul do Brasil
}

\section{Sabrina Amaral Pereira, Cláudio Rossano Trindade Trindade, Edélti Faria Albertoni and Cleber Palma-Silva}

\author{
Laboratório de Limnologia, Instituto de Ciências Biológicas, \\ Universidade Federal do Rio Grande - FURG, Av. Itália, Km 8, CEP 96201-900, Rio Grande, RS, Brazil \\ e-mail: sabri.pereira@hotmail.com; claudio.trindade@furg.br; dmbefa@furg.br; dmbcps@furg.br
}

\begin{abstract}
Aims: We evaluated the potential of aquatic macrophyte communities as bioindicators in six small shallow lakes. Methods: The sampling was conducted monthly for one year, during which all macrophytes were surveyed, and the water temperature, dissolved oxygen, $\mathrm{pH}$, conductivity, total alkalinity, chlorophyll- $a$, suspended matter, total nitrogen $(\mathrm{Nt})$ and total phosphorus $(\mathrm{Pt})$ were measured. Results: In total, forty-three species were recorded, and there were significant differences in the species richness and limnological conditions among the lakes studied. A canonical correspondence analysis showed that the concentration of nutrients ( $\mathrm{Nt}$ and $\mathrm{Pt}$ ), chlorophyll- $a$, suspended matter, dissolved oxygen and $\mathrm{pH}$ were the most important predictors of the distribution of macrophytes. Some emergents were related to the high concentration of nutrients, chlorophyll- $a$, and suspended matter. Moreover, the most submersed species were associated with environments with low nutrient concentrations and the lowest values chlorophyll- $a$ and suspended matter. In addition, some species submerged and floating were related to low values $\mathrm{pH}$, alkalinity and dissolved oxygen. Limnological differences between lakes may be cited as the main causes of the observed heterogeneous distribution of macrophytes. Conclusions: These results indicate the importance of limnological characteristics of the different environments in the macrophyte community composition and the potential role of this community as a bioindicator in shallow lakes in southern Brazil.
\end{abstract}

Keywords: bioindicators, aquatic vegetation, shallow lakes, eutrophication.

Resumo: Objetivo: Foi avaliado o potencial bioindicador da comunidade de macrófitas aquáticas em seis pequenos lagos rasos. Métodos: $\mathrm{O}$ acompanhamento foi mensal durante um ano, sendo que em cada coleta, além do registro de todas as espécies de macrófitas foram determinadas a temperatura da água, oxigênio dissolvido, $\mathrm{pH}$, condutividade elétrica, alcalinidade total, clorofila- $a$, material em suspensão, nitrogênio total $(\mathrm{Nt})$ e fósforo total $(\mathrm{Pt})$. Resultados: No total, quarenta e três espécies foram registradas, e ocorreram diferenças significativas na riqueza de espécies e nas condições limnológicas entre os lagos estudados. A análise de correspondência canônica mostrou que a concentração de nutrientes $(\mathrm{Nt}$ e Pt), clorofila- $a$, material em suspensão, oxigênio dissolvido e $\mathrm{pH}$ foram os mais importantes preditores da distribuição das macrófitas aquáticas. Algumas espécies emergentes estiveram relacionadas à alta concentração de nutrientes, de clorofila- $a$, e de material em suspensão. Por outro lado, a maioria das espécies submersas foram associadas a ambientes com baixa concentração de nutrientes e os menores valores de clorofila- $a$, e de material em suspensão. Além disso, algumas espécies submersas e flutuantes foram relacionadas a baixos valores $\mathrm{de} \mathrm{pH}$, alcalinidade e oxigênio dissolvido. As diferenças limnológicas entre os lagos podem ser apontadas como as principais causas da distribuiçẫo heterogênea observada das macrófitas. Conclusóes: Estes resultados indicam a importância das características limnológicas dos diferentes ambientes na composição da comunidade de macrófitas aquáticas e o potencial papel bioindicador dessa comunidade em lagos rasos do sul do Brasil.

Palavras-chave: bioindicadores, vegetação aquática, lagos rasos, eutrofização. 


\section{Introduction}

Aquatic macrophytes compose an important community in limnic ecosystems because, in most cases, they are the main primary producers, they produce high biomass, and they contribute to biodiversity (Wetzel, 1993; Esteves, 1998). Macrophytes in shallow lakes are involved in various feedback mechanisms that tend to maintain a clear water state (Scheffer, 1998).

This community has a large ecological amplitude (Esteves, 1998; Thomaz, 2002) and therefore may colonize environments with different ecological characteristics (Thomaz and Bini, 1998) and withstand sudden environmental changes (Menezes et al., 1993; Esteves, 1998).

Macrophytes are organisms with low mobility and cannot avoid any combination of flow, nutrient availability and other physical and chemical characteristics that influence their survival in aquatic systems. Thus, an assembly of such organisms in a river or lake can be an effective indicator of the integrated combination of the pressure and stress disorders that affect their habitat (Murphy, 2000).

Several studies have analyzed environmental factors associated with the richness and species composition of macrophytes (Bini et al., 1999; Virola et al., 2001; Maltchik et al., 2002; Thomaz et al., 2003; Heegaard, 2004; Rolon et al., 2004). It is clear that macrophytes are limited to a set of characteristics of a specific habitat (Murphy, 2002) and that they respond differently to environmental conditions (e.g., trophic status) (Barko et al., 1986; Van Geest, 2005). When all habitat conditions are known, the distribution of plant species can be satisfactorily provided (Guisan and Zimmermann, 2000). Recently, many efforts have been made in developing a biotic index based on macrophytes and predictive models that can be used as management tools in monitoring the quality of water bodies (Camargo et al., 2003; Ciecierska, 2006; Clayton and Edwards, 2006; Joye et al., 2006; Beck et al., 2010; Kocic et al., 2008; Penning et al., 2008a, b; Søndergaard, 2010).

In the coastal plain of Rio Grande do Sul, there are common and diverse dense macrophyte stands in their aquatic environments (Albertoni et al., 2005). The present study investigated six lakes of the coastal plain of Rio Grande do Sul with different limnological characteristics, aiming i) to identify the community of aquatic macrophytes and ii) to verify the importance of species composition as a predictor of limnological characteristics. Our hypothesis is that this community is different according to limnological characteristics of the ecosystems studied, so that ecological groups indicate such environmental variations.

\section{Material and Methods}

\subsection{Study area}

The study was conducted in six shallow lakes on the campus of the Federal University of Rio Grande - FURG ( $32^{\circ} 04^{\prime} 43^{\prime \prime} S$ and $\left.52^{\circ} 10^{\prime} 03^{\prime \prime} \mathrm{W}\right)$, municipality of Rio Grande, Rio Grande do Sul, Brazil (Figure 1). The city of Rio Grande is located in southern Brazil on the Rio Grande do Sul Coastal Plain. The coastal plain is characterized by low relief and by the absence of rivers. Streams and ponds constitute the hydrographic network (Vieira and Rangel, 1988). The climate is humid subtropical (Cfa according to the Köppen classification), with average annual temperature varies between $13{ }^{\circ} \mathrm{C}$ (winter) and $24^{\circ} \mathrm{C}$ (summer). The winter and spring are characterized by intense humidity, and the summer is dry, with total annual rainfall is between 1200 and $1500 \mathrm{~mm}$ (Klein, 1998). NE winds dominate for most of the year. In the autumn, and particularly in winter, $S$ (mainly SE) winds become very important (Krusche et al., 2002).

The campus has about 250 ha of land, a great number of small natural and artificial water bodies, which due to the geomorphological characteristics of the region, have a gentle slope at the edge of the coastal region where providing a large area where, during periods of high rainfall, the soil remains saturated. These environments have different limnological and trophic levels, which enable the development of unique biological communities (Albertoni et al., 2005; Marinho et al., 2009; Trindade et al., 2009).

Dunas Lake (4) is a shallow body of water situated along a strip of dunes, and the area and depth are greatly influenced by the seasonal rainfall pattern in the region, ranging from a $1.5 \mathrm{~m}$ to a few centimeters deep (Trindade, 2008). During periods of high rainfall, the littoral zone remains submerged, forming an extensive lake. In dry periods, the water flow is reduced, creating small ponds connected by wetlands; the littoral zone is then an area that can be characterized by habitat heterogeneity.

Polegar Lake (5) is an artificial lake, built about 14 years ago, that has an area of about 1 ha and a maximum depth of $1.6 \mathrm{~m}$. The Negro Lake (1) has a rounded shape with an area of $0.5 \mathrm{ha}$, a maximum depth of $3.10 \mathrm{~m}$ and dystrophic features (Albertoni et al., 2005). Present in its surroundings 
is Eucalyptus sp., which shades the lake and protects it from the wind and contributes continuously to the input of organic matter, the decomposition of which releases humic substances that lead to the darkening water.

The Reitoria Lake (2) is a wetland, and its depth varies with rainfall, not exceeding $2 \mathrm{~m}$ deep. Tree species along the lake edges supply organic matter to the lake. The Biguás Lake (3) has a surface area of about 1.5 ha and a maximum depth of $2 \mathrm{~m}$. In this lake, there are two small islands, which often serve as shelters and resting places for cormorants, herons, ducks and geese. These birds contribute inputs of organic matter and are the lake's main source of enrichment, accelerating the process of eutrophication (Trindade et al., 2009). Lake Centro Esportivo (6) has a round shape, with depth of approximately 2 meters, and high water transparency. Its environment is composed of shrubs and grasses that protect it from erosion.

\subsection{Methodology}

The sampling was conducted monthly during 2008 and consisted of surveying the species present in each lake and the limnological characteristics of the environment. The species survey was conducted by walking through the environments until there was no further increase in the number of species (Filgueiras et al., 1994). The sampling effort was proportional to the size of the environment sampled to get a better picture of the total number of species in each environment. The identification followed the taxonomic literature (Forno, 1983; Cordazzo and Seelinger, 1988, Cook, 1990; Irgang and Gastal Junior, 1996; Pott and Cervi, 1999; Gil and Bove, 2007; Barros, 1960). The angiosperms species were arranged by family according to APG II - Angiosperm Phylogeny Group (2003), the pteridophytas according Tryon and Tryon (1982) and algae Van-de-Hoeck et al. (1995). The ecological groups were classified according to Irgang and Gastal Junior (1996).

The limnological characteristics that were analyzed in situ were the water temperature $\left({ }^{\circ} \mathrm{C}\right)$, dissolved oxygen (mg. $\left.\mathrm{L}^{-1}\right), \mathrm{pH}$ and conductivity $\left(\mu \mathrm{S} . \mathrm{cm}^{-1}\right)$. A subsurface water sample was brought to the laboratory to determine total alkalinity (mEq.L $\mathrm{L}^{-1}$ ) (Carmouze, 1994), total nitrogen (mg. $\left.\mathrm{L}^{-1}\right)$ (Mackereth and Talling, 1978), total

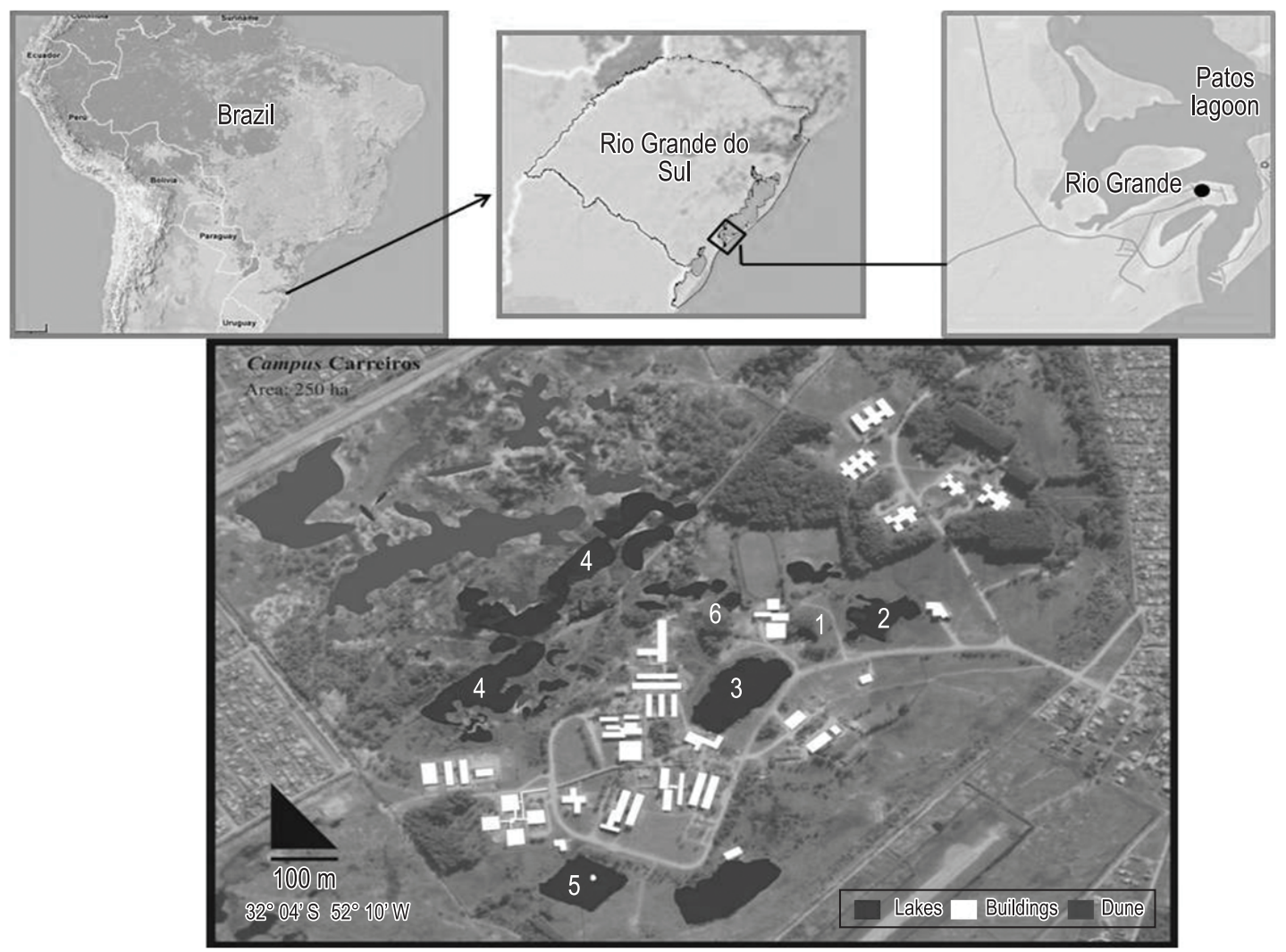

Figure 1. Location of study area (Carreiros campus, FURG, Rio Grande, Rio Grande do Sul, Brazil). Codes lakes: 1 - Negro; 2 - Reitoria; 3 - Biguás; 4 - Dunas; 5 - Polegar; 6 - Centro Esportivo. 
phosphorus ( $\left.\mu \mathrm{g} . \mathrm{L}^{-1}\right)$ (Valderrama, 1981), suspended matter (mg. $\left.\mathrm{L}^{-1}\right)$ (Paranhos, 1996) and chlorophyll- $a$ (mg. $\mathrm{L}^{-1}$ ) (Chorus and Bartram, 1999). Sampling of variables were performed at the same time (between $10 \mathrm{~h}$ and $12 \mathrm{~h}$ ) and in triplicate. The classification of trophic state of studies lakes followed previous studies (Albertoni et al., 2005, 2007; Marinho et al., 2009; Trindade et al., 2008, 2009), and the lakes Dunas, Reitoria and Centro Esportivo are classified as mesotrophic, Polegar as oligotrophic, Negro as dystrophic and Biguás as eutrophic.

Macrophyte richness were determined for total number and average annual number of species recorded in each environment and frequency for proportion of lakes where the species occurred and the number de occurrences during the year in each lake. The differences in mean species richness and abiotic variables throughout the year (for season) and among the lakes studied were tested using a repeated measures ANOVA, with an a posteriori Tukey test.

The influence of environmental variables on species composition was analyzed with a Canonical Correspondence Analysis (CCA) (Ter Braak, 1986). For environmental variables were done "a priori" test (ANOVA repeated) that showed significant differences between lakes, but not differences among year seasons in each lake ( $p>0.05)$. Then, the CCA was based on the frequency of species recorded over the study period in each environment and average annual data for abiotic variables (all variables were log-transformed). The frequency values ranged from zero (absent in the environment) to 12 (present during the 12 months of collection).

\section{Results}

Throughout the study, a total of 43 macrophyte species were recorded (Table 1). The distribution of species at each lake during the study is show in Figure 2. The species Luziola peruviana Juss. ex J. F. Gmel. was the only species found in all environments. Alternanthera philoxeroides (Mart.) Griseb., Bacopa monnieri (L.) Pennell, Azolla filiculoides Lam., Centella asiatica (L.) Urb., Hydrocotyle bonariensis Lam. and Ludwigia peploides (Kunth) P.H.Raven were found in more than $80 \%$ of the lakes studied. However, most species $(70 \%)$ were found in less than $50 \%$ of the lakes. Considering all lakes, the species richness of macrophytes did not differ significantly throughout the seasons $\left(\mathrm{F}_{3.68}=0.10979, \mathrm{p}=0.954\right)$. However, richness was significantly different between lakes $\left(\mathrm{F}_{5.66}=407.06, \mathrm{p}<0.001\right)$ (Figure 3). The Dunas
Lake had the highest richness (mean $=31.91$, SD = 1.62), and Polegar Lake had the lowest richness $($ mean $=7.16, \mathrm{SD}=0.83)$. Only Lakes Centro Esportivo and the Reitoria did not differ in species richness $(\mathrm{p}=0.378)$.

The classification of ecological groups showed that in all the lakes, there was a predominance of emergent or amphibious species, which comprised $90 \%$ of the species (Figure 2). We found all ecological groups only in lakes Dunas and Centro Esportivo. At Biguás lake, there were no submersed species (free and/or rooted), and at lakes Reitoria and Negro, the submerged rooted biotype was absent. In Lake Polegar there were not free-floating and submerged aquatic macrophytes.

Table 2 shows the average values of abiotic variables for each lake. The Negro Lake had the lowest $\mathrm{pH}$, temperatures and dissolved oxygen concentration and can be considered an acid lake with dystrophic features as described by Albertoni et al. (2005). The Biguás Lake had significantly higher values for all of the abiotic variables analyzed, including a slightly basic $\mathrm{pH}$ and high concentrations of chlorophyll- $a$, dissolved oxygen and nutrients (nitrogen and total phosphorus), and may be characterized as a eutrophic environment, as described by Trindade et al. (2009). The lakes Dunas and Polegar had near-neutral $\mathrm{pH}$. Polegar Lake showed oligotrophic characteristics, with lower values of chlorophyll- $a$ and nutrient concentrations, while Dunas Lake, which has an oligo-mesotrophic environment, showed intermediate values for these variables. Lake Centro Esportivo and the Reitoria did not differ with respect to abiotic variables, both being characterized as mesotrophic.

The first two CCA axes together explained $65.87 \%$ of the variation in species composition (Figure 4). Nutrient concentrations ( $\mathrm{Nt}$ and $\mathrm{Pt}$ ), chlorophyll- $a$, suspended matter, dissolved oxygen and $\mathrm{pH}$ were the most important predictors of the distribution of macrophytes. The emergent/ amphibious species, Cyperus odoratus L., Polygonum ferrugineum Wedd., Polygonum hydropiperoides Michx, A. philoxeroides, Vigna luteola (Jacq.) Benth., L. peploides, Enydra anagallis Gardner, were strongly associated with characteristics of eutrophic environments, that is directly related to higher concentrations and/or values of the predictors of the distribution. The submerged species, including Cabomba caroliniana A. Gray, Nitella sp. and Chara sp.,and floating Wolffia brasiliensis Wedd. were associated with the lowest concentration 
Table 1. List of species and ecological groups of aquatic macrophytes found in six lakes of the campus Carreiros of Rio Grande, Rio Grande do Sul, Brazil. Frequency (\%) represents the proportion of lakes where the species appeared throughout the study.

\section{CHARACEAE - Chlorophyta}

Chara sp.

Nitella sp.

Cha

Nit

Submerged rooted

\section{SALVINACEAE - Pteridophyta}

Azolla filiculoides Lam.

Salvinia herzogii de la Sota

Salvinia minima Baker

Azol

Savh

Savm

Free floating

\section{ALISMATACEAE - Angiosperms}

Echinodorus tenellus (Mart.) Buchenau

Sagittaria montevidensis Cham. \& Schltdl.

\section{AMARANTHACEAE}

Alternanthera philoxeroides (Mart.) Griseb.

\section{APIACEAE}

Centella asiatica (L.) Urb.

\section{ARACEAE}

Lemna valdiviana Phil.

Pistia stratiotes $\mathrm{L}$.

Wolffia brasiliensis Wedd.

Wolffiella oblonga (Phil.) Hegelm.

\section{ARALIACEAE}

Hydrocotyle bonariensis Lam.

Hydrocotyle ranunculoides L.f.

\section{ASTERACEAE}

Mikania periplocifolia Hook. \& Arn.

Enydra anagallis Gardner

\section{CABOMBACEAE}

Cabomba caroliniana A.Gray

\section{CYPERACEAE}

Androtrichum trigynum (Spreng.) H.Pfeiff.

Ascolepis brasiliensis (Kunth) Benth. ex C.B.Clarke

Cyperus haspan L.

Cyperus odoratus L.

Cyperus rigens C.Presl

Pycreus polystachyos (Rottb.) P.Beauv.

Schoenoplectus californicus (C.A.Mey.) Soják

Scirpus giganteus Kunth

\section{FABACEAE}

Erythrina crista-galli L.

Vigna luteola (Jacq.) Benth.

\section{LENTIBULARIACEAE}

Utricularia breviscapa C.Wright ex Griseb.

Utricularia gibba L.

\section{MENYANTHACEAE}

Nymphoides indica (L.) Kuntze

\section{ONAGRACEAE}

Ludwigia multinervia (Hook. \& Arn.) Ramamoorthy Ludwigia hexapetala (Hook. \& Arn.) Zardini et al. Ludwigia peploides (Kunth) P.H.Raven

\section{PLANTAGINACEAE}

\begin{tabular}{|c|c|c|}
\hline Ech & Emergent/amphibious & 33 \\
\hline Sagm & Emergent/amphibious & 17 \\
\hline Alt & Emergent/amphibious & 83 \\
\hline Cen & Emergent/amphibious & 83 \\
\hline Lva & Free floating & 50 \\
\hline Pis & Free floating & 17 \\
\hline Wofb & Free floating & 17 \\
\hline Wof & Free floating & 17 \\
\hline Hyb & Emergent/amphibious & 83 \\
\hline Hyr & Emergent/amphibious & 50 \\
\hline Mik & Amphibious & 17 \\
\hline Eny & Emergent/amphibious & 83 \\
\hline $\mathrm{Cab}$ & Submerged rooted & 17 \\
\hline Andt & Emergent/amphibious & 17 \\
\hline Ascb & Emergent/amphibious & 17 \\
\hline Cyph & Emergent/amphibious & 33 \\
\hline Сypo & Emergent/amphibious & 50 \\
\hline Cypr & Emergent/amphibious & 33 \\
\hline Руср & Emergent/amphibious & 17 \\
\hline Scl & Emergent/amphibious & 50 \\
\hline Scg & Emergent/amphibious & 50 \\
\hline Ery & Emergent/amphibious & 17 \\
\hline Vig & Emergent/amphibious & 33 \\
\hline Utrb & Free submerged & 67 \\
\hline Utrg & Free submerged & 67 \\
\hline Ny & Rooted with floating leaves & 50 \\
\hline Ludm & Emergent/amphibious & 50 \\
\hline Ludh & Emergent/amphibious & 83 \\
\hline Ludp & Emergent/amphibious & 83 \\
\hline Bac & Emergent/amphibious & 83 \\
\hline
\end{tabular}


Table 1. Continued...

\begin{tabular}{|c|c|c|c|}
\hline Family/Species & Species code & Morpho-ecology group & Frequency (\%) \\
\hline \multicolumn{4}{|l|}{ POACEAE } \\
\hline Luziola peruviana Juss. ex J.F.Gmel. & Luz & Emergent/amphibious & 100 \\
\hline \multicolumn{4}{|l|}{ POLYGONACEAE } \\
\hline Polygonum ferrugineum Wedd. & Polf & Emergent/amphibious & 50 \\
\hline Polygonum hydropiperoides Michx. & Polh & Emergent/amphibious & 67 \\
\hline \multicolumn{4}{|l|}{ PONTEDERIACEAE } \\
\hline Eichhornia crassipes (Mart.) Solms & Eic & Free floating & 33 \\
\hline \multicolumn{4}{|l|}{ POTAMOGETONACEAE } \\
\hline Potamogeton pectinatus $\mathrm{L}$. & Potp & Submerged rooted & 33 \\
\hline \multicolumn{4}{|l|}{ SALICACEAE } \\
\hline Salix humboldtiana Willd. & Salx & Emergent/amphibious & 17 \\
\hline \multicolumn{4}{|l|}{ TYPHACEAE } \\
\hline Typha domingensis Pers. & Tyd & Emergent/amphibious & 17 \\
\hline \multicolumn{4}{|l|}{ XYRIDACEAE } \\
\hline Xyris jupicai Rich. & Xyj & Emergent/amphibious & 67 \\
\hline
\end{tabular}

Table 2. Annual mean and standard deviation of abiotic variables in the water column of the six lakes studied. $\mathrm{T}^{\circ} \mathrm{C}$ : Water temperature $\left({ }^{\circ} \mathrm{C}\right)$; DO: Dissolved Oxygen $\left(\mathrm{mg} . \mathrm{L}^{-1}\right)$, C: Conductivity $\left(\mu \mathrm{S} . \mathrm{cm}^{-1}\right)$, TA: Total Alkalinity $\left(\mathrm{mEq} . \mathrm{L}^{-1}\right)$; Chla: Chlorophyll-a ( $\mu$ g. $\left.\mathrm{L}^{-1}\right)$, SM: suspended matter $\left(\mathrm{mg} . \mathrm{L}^{-1}\right) \mathrm{TN}$ : Total Nitrogen $\left(\mathrm{mg} . \mathrm{L}^{-1}\right)$, TP: Total Phosphorus $\left(\mu \mathrm{g} . \mathrm{L}^{-1}\right)$. Codes of trophic states of lakes: O - Oligotrophic; M - Mesotrophic and E - Eutrophic.

\begin{tabular}{lccccccc}
\hline & Dunas (M) & Polegar (O) & Negro (D) & CE (M) & Reitoria (M) & Biguás (E) & p-value \\
\hline $\mathbf{T}^{\circ} \mathbf{C}$ & $20.72 \pm 3.71$ & $20.08 \pm 4.06$ & $18.22 \pm 3.52$ & $19.7 \pm 4.16$ & $21.09 \pm 4.14$ & $19.88 \pm 4.58$ & $\mathrm{n} . \mathrm{s}$. \\
$\mathbf{p H}$ & $6.53 \pm 0.40$ & $6.51 \pm 0.50$ & $4.66 \pm 0.28$ & $5.92 \pm 0.26$ & $5.56 \pm 0.24$ & $8.11 \pm 1.05$ & $* *$ \\
OD & $4.88 \pm 1.06$ & $6.79 \pm 0.87$ & $1.54 \pm 0.59$ & $4.10 \pm 0.71$ & $3.81 \pm 1.10$ & $8.58 \pm 1.41$ & $* *$ \\
$\mathbf{C E}$ & $154.57 \pm 17.39$ & $72.9 \pm 12.73$ & $99.62 \pm 10.50$ & $111.06 \pm 21.24$ & $77.7 \pm 5.29$ & $191.19 \pm 28.60$ & $* *$ \\
AT & $1.20 \pm 0.30$ & $0.44 \pm 0.14$ & $0.14 \pm 0.28$ & $0.83 \pm 0.25$ & $0.37 \pm 0.06$ & $1.54 \pm 0.13$ & $* *$ \\
Chla & $20.27 \pm 21.54$ & $18.56 \pm 11.28$ & $37.28 \pm 25.50$ & $20.80 \pm 7.50$ & $40.35 \pm 31.95$ & $152.38 \pm 85.83$ & $*$ \\
MS & $5.47 \pm 5.03$ & $7.08 \pm 3.37$ & $8.7 \pm 5.06$ & $4.32 \pm 2.48$ & $6.02 \pm 8.31$ & $52.36 \pm 27.82$ & $*$ \\
Nt & $0.67 \pm 0.11$ & $0.47 \pm 0.13$ & $1.12 \pm 0.08$ & $0.88 \pm 0.31$ & $0.88 \pm 0.10$ & $3.75 \pm 1.29$ & $* *$ \\
Pt & $41.64 \pm 36.48$ & $28.60 \pm 16.58$ & $60.94 \pm 11.89$ & $34.64 \pm 12.89$ & $29.87 \pm 5.59$ & $256.96 \pm 64.76$ & $* *$ \\
\hline
\end{tabular}

Nomenclature - n.s. (not significant), ${ }^{*} \mathrm{p}<0.01$ and ${ }^{* *} \mathrm{p}<0.001$.

of chlorophyll-a, low suspended matter and concentrations of nutrients, while free-floating species Salvinia herzogii de la Sota, Pistia stratiotes L. and Salvinia minima Baker were associated with intermediate conditions.

The other two submerged species, Utricularia breviscapa C. Wright ex Griseb. and Utricularia gibba L., and floating species Lemna valdiviana Phil., Wolffiella oblonga (Phil.) Hegelm., and A. filiculoides were more related to low values of $\mathrm{pH}$, alkalinity, dissolved oxygen, probably reflecting their high frequency of occurrence in the lakes Negro and Centro Esportivo.

It may be noted that $L$. peruviana was located near the center of the chart, suggesting that the different characteristics of the study sites do not seem to markedly affect this species.

\section{Discussion}

Studies have shown a similar pattern of colonization and diversity of macrophytes in wetlands of Rio Grande do Sul, with a predominance of emergent and amphibious species. These species, normaly, have frequency of occurrence rare in different environments, (Rolon et al., 2004, 2008, 2010; Maltchik et al., 2007). The environments in the present study also followed this pattern, with only seven widely distributed species, and in all lakes, the most common species were emergent or amphibious. Shallow water environments with frequent fluctuations in their levels of flooding favor the development of these biotypes (Esteves, 1998; Albertoni et al., 2005; Sponchiado and Schwarzbold, 2008).

The distribution of macrophytes in lakes has been related by many authors with the 


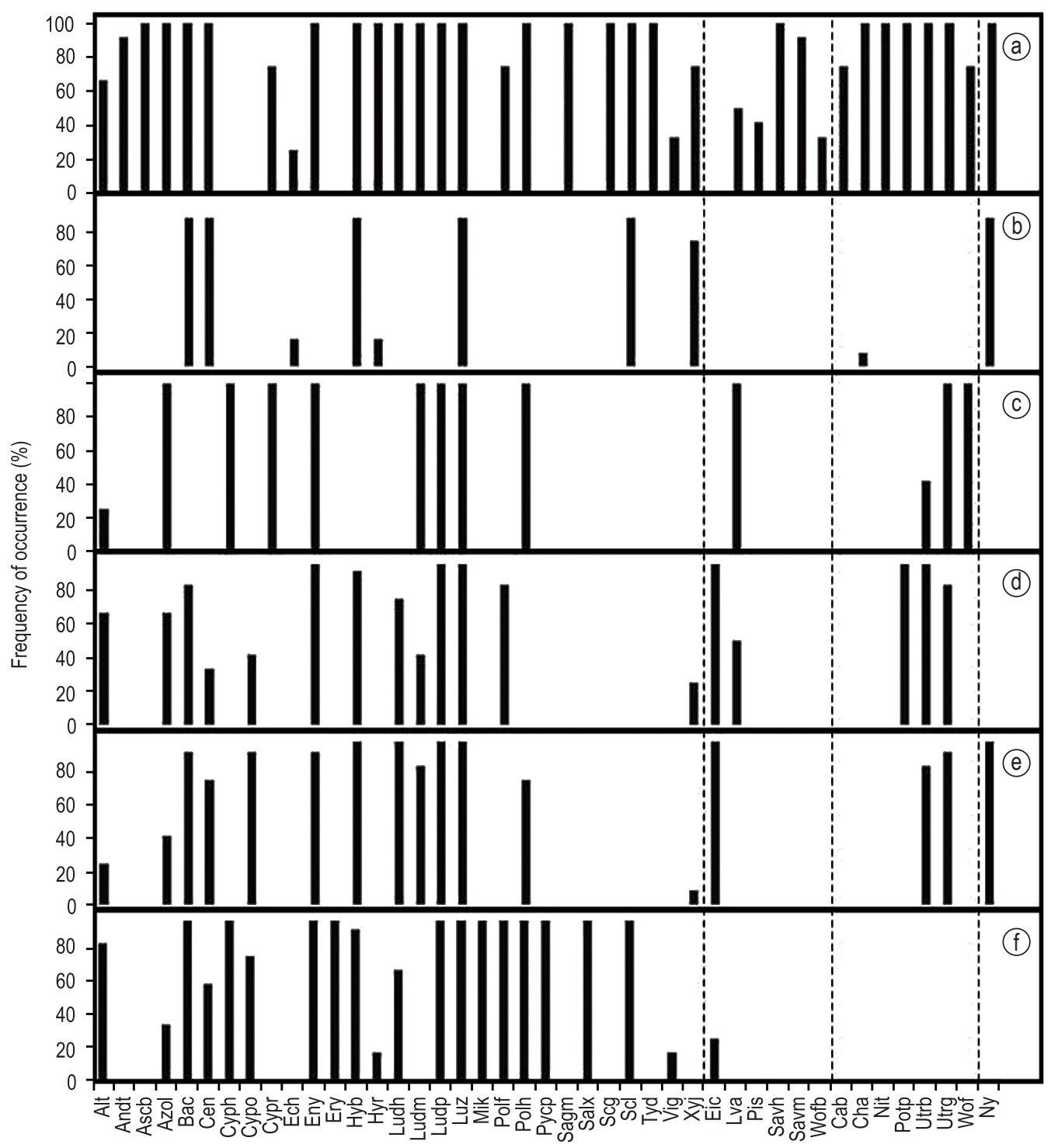

Figure 2. Map of distribution of frequency of occurrence (\%) of species in each lake throughout the study. The species are separated for ecological groups: 1 - emergent/amphibious; 2 - floating; 3 - submerged and 4 - rooted with floating leaves. Codes lakes: a - Dunas; b - Polegar; c - Negro; d - Centro Esportivo; e - Reitoria e f - Biguás. Codes species: See Table 1.

limnological characteristics of the environments, such pH (Vestergaard and Sand-Jensen, 2000; Catling et al., 1986; Jackson and Charles, 1988), and concentrations of chlorophyll and nutrients (Rørslett, 1991: Murphy, 2002; Bini, 1999). Our results showed that the different limnological characteristics of each environment seem to influence the success of the species.

The values of the abiotic variables are similar to those found in other studies of shallow water environments (Albertoni et al., 2005, 2007; Marinho, 2009; Trindade et al., 2008, 2009).
The small seasonal variation found in these values may be the result of morphometric features of the environments and climate in the region because, according to Trindade et al. (2009), the low depth associated with the constant wind action causes the homogenization of the water column in the lakes, and daily variations become more pronounced than seasonal ones. However, the heterogeneity of the limnological characteristics of lakes studied appears to have been determinant in structuring the aquatic macrophyte community. 
Several studies have documented that the trophic state and light conditions in the environment can influence the development and colonization of aquatic macrophytes (Mitchell, 1974; Wetzel, 1990; Esteves, 1998; Scheffer, 1998; Thomaz and Bini, 1998; Thomaz, 2002; Nurminen, 2003; Kocic et al., 2008; Penning et al., 2008a). In this study, the concentrations of nutrients $(\mathrm{Nt}$ and $\mathrm{Pt}$ ) and the abiotic variables related to the radiation attenuation (chlorophyll- $a$ and suspended matter) were the main predictors for the variation of macrophytes. These results indicate that the trophic characteristics of the different environments influence the composition of macrophyte communities in shallow lakes.

However, other studies have shown that several water chemistry variables such as $\mathrm{pH}$ (Catlinge et al., 1986) and alkalinity (Jackson and Charles, 1988) also exert strong influence on the distribution of macrophytes, especially submerged ones (Vestergaard and Sand-Jensen, 2000). In this study it was shown that these variables were also important in the occurrence of some species.

Different forms of life require different nutrient sources and have variable tolerances of exposure to environmental characteristics (Toivonen and Huttunen, 1995). In the lakes studied, some emergent and amphibious species were tolerant of high trophic conditions and poor lighting conditions. Studies have shown that emergent macrophytes may occur in areas with turbid water that is nutrient rich; for example, at a large lake in the southwest coast of Finland, the diversity and richness of emergent species increased with the trophic status of the lake (Nurminen,

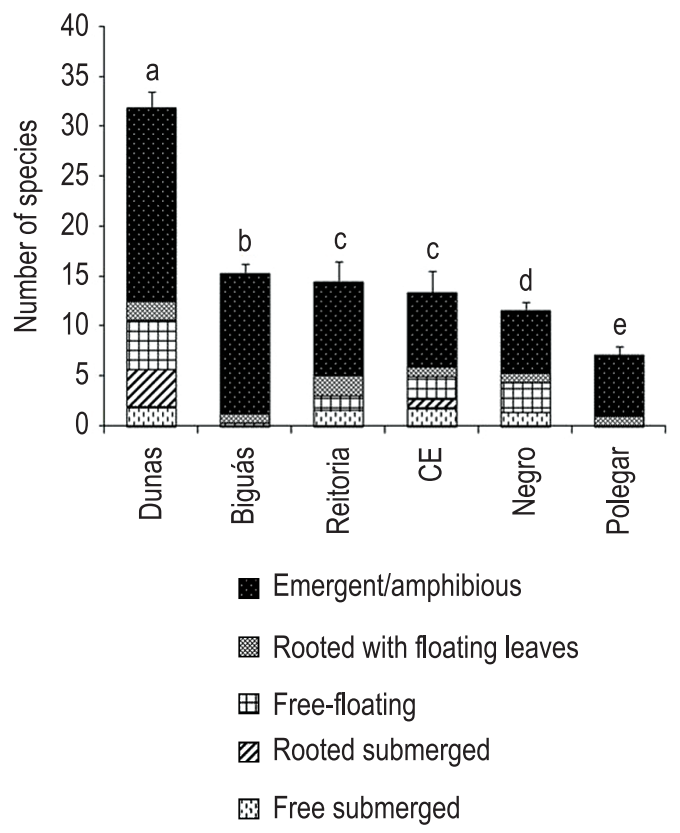

Figure 3. Average annual richness and ecological groups of aquatic macrophytes found in six shallow lakes of the Carreiros campus. Values represent the mean and standard deviation of species richness throughout the study. Different letters represent significant differences in species richness among lakes $(\mathrm{p}<0.001)$.

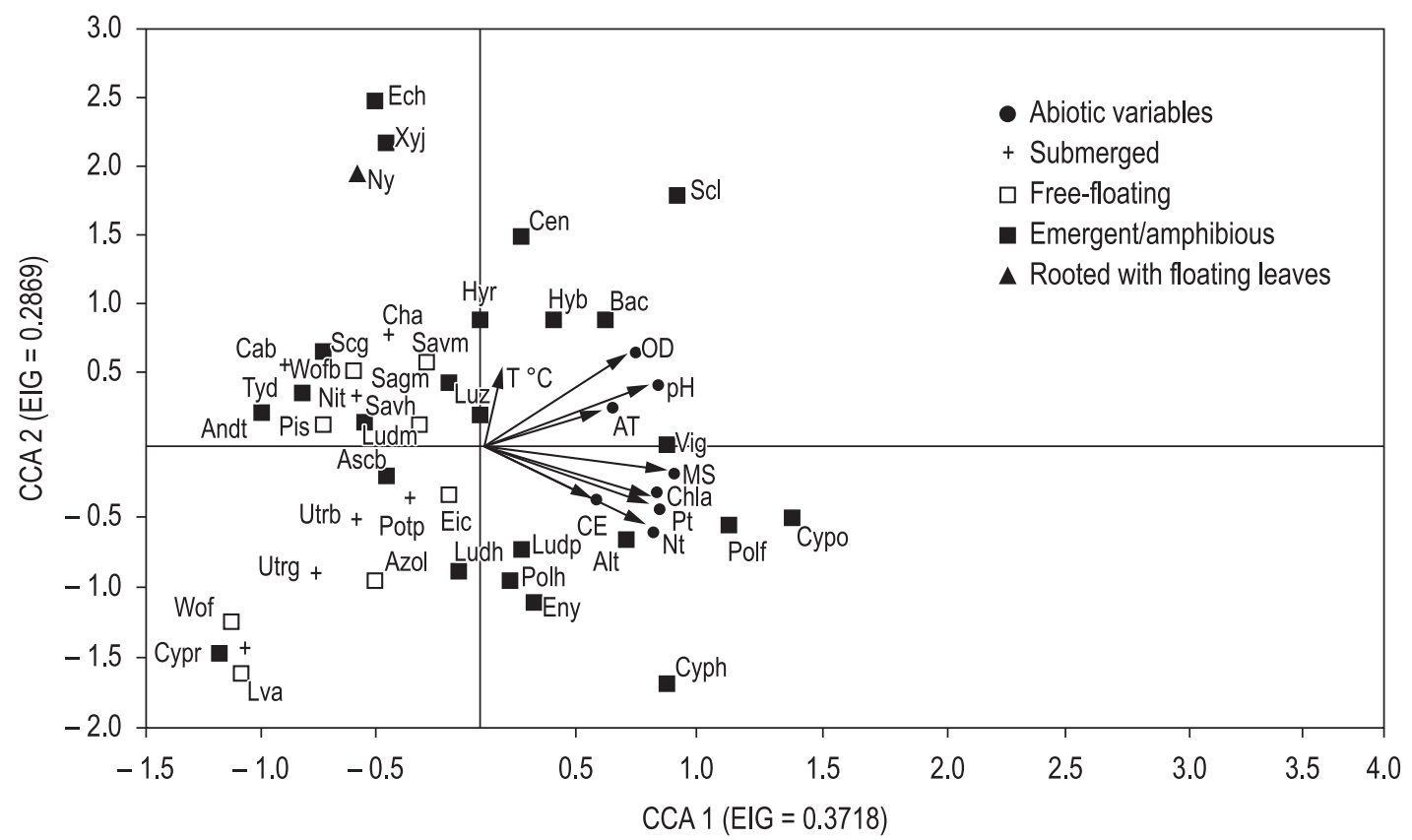

Figure 4. Diagram of the CCA ordination with the composition of species, the lakes and environmental variables in the vectors studied. (EIG = eigenvalues of axes). For the definitions of the environmental variables, see Table 2 codes. For species codes, see Table 1. 
2003). Camargo et al. (2003) report that highly productive environments have a marked growth of phytoplankton, which limits the growth of submerged and floating species but not the rooted macrophytes, which use the sediment as their main source of nutrients.

Our results showed that free-floating species were also related to intermediate nutrient concentrations. This ecological group gets its nutritional requirements from the water column (Bini et al., 1999; Thomaz, 2002), then its association with the nutrients may be a direct result of these nutrients facilitating its growth. Moreover, some of these species, such as E. crassipes, have vegetative growth, which confers a competitive advantage for obtaining nutrients in the environment. Many studies have demonstrated great potential for the proliferation of some floating species (Reddy and DeBusk, 1985; Bini et al., 1999; Thomaz, 2002; Camargo et al., 2003), which can cause serious damage not only to the multiple uses of water but also to other communities in the environment.

In this study, the environment with oligotrophic characteristics and low concentrations of nutrients (Polegar Lake) did not provide a favorable environment for the growth of floating macrophytes. However, the Biguás Lake, which had nutrient-rich water, had no species in this ecological group. According to Heegaard et al. (2001), an increase in the concentration of nutrients can promote biological diversity; however, the continuity of this process can lead to a decrease in biodiversity, the disappearance of some plant species and the appearance of others. Thus, the accelerated process of eutrophication in this lake mainly allows the development of some emerging or amphibious species, which dominate the environment.

Most of the submerged species are limited by the attenuation of radiation and are indicative of environments with low nutrient concentrations (Scheffer, 1998; Thomaz, 2002; Camargo et al., 2003). Similarly, the species C. caroliniana, Nitella sp. and Chara sp. were related to characteristics of environments with this characteristics, as found in the Lake Polegar and Dunas. At the two lakes with values greater concentrations of nutrients and suspended material (Negro and Biguás), species of this biotype were not found. Their absence is possibly related to the high marked hypertrophy and growth of phytoplankton in the lake Biguás and dystrophic features (high decomposition of humic substances) in the Negro Lake, which cause poor lighting conditions. These results indicate that increased eutrophication and turbidity can result in a reduction or elimination of submerged macrophytes, and their presence in the environment can be a strong indicator of good water quality. Moreover, according to Palma-Silva et al. (2002), submerged species such as Charophyta have an important role in bottom-up control of phytoplankton by maintaining a clear water state.

However, studies have documented that some species may be strongly influenced by $\mathrm{pH}$ and alkalinity, as these variables are closely related to the concentrations of bicarbonate an important source of inorganic carbon for photosynthesis and growth of submerged species (Catling et al., 1986; Jackson and Charles, 1988; Spence and Maberly, 1985; Madsen and SandJensen, 1991). Vestergaard and Sand-Jensen (2000) in Danish lakes have documented that acidic lakes with low alkalinity are generally poor in submerged species. In the present study the submerged species U. breviscapa C. Wright ex Griseb. and U. gibba L., and floating L. valdiviana Phil., W. oblonga (Phil.) Hegelm and $A$. filiculoides were related to low values of $\mathrm{pH}$, alkalinity and dissolved oxygen, as found in Negro lake. According to some studies (Spence and Maberly,1985; Vestergaard and Sand-Jensen, 2000) the modes of carbon use, and therefore the concentration of bicarbonate (alkalinity and $\mathrm{pH}$ ), differ among taxonomic groups and also between species with same growth form. These results indicate these species appear to have been favored by such conditions.

The species $L$. peruviana was widely distributed in the studied environment and was not directly influenced by the different environmental characteristics. According to Sponchiado and Schwarzbold (2008), this species is dominant in shallow ponds. This dominance is possibly derived from its growth from plugs and its good resprouting ability throughout the year (Neiff, 2000; Boldrini et al., 2005).

The different ecological groups of aquatic macrophyte communities in the lakes were effective indicators of environmental characteristics, mainly trophic status and luminosity. Emergent or amphibious species were related to high concentrations of nutrients and poor lighting conditions (high chlorophyll- $a$ and suspended matter), while free-floating were related to intermediate concentrations. In contrast, the submerged species were good indicators of environments with characteristics of low concentration of nutrients. However, we point 
out the importance of other water chemistry variables such $\mathrm{pH}$, alkalinity and dissolved oxygen in the distribution of some species of macrophytes, especially submerged.

Our hypothesis was supported because differences in limnological characteristics of the lakes were reflected in the aquatic vegetation and can be identified as a major cause of macrophyte heterogeneity. These results indicate the importance of limnological characteristics of different environments (especially the trophic status and luminosity) in the macrophyte community composition and the potential role for this community as a bioindicator in shallow lakes in southern Brazil.

\section{Acknowledgements}

We thank the members of the laboratory of Limnology (ICB/FURG), and Dra. Sônia M. Hefler for his suggestions in taxonomy.

\section{References}

ALBERTONI, EF., PALMA-SILVA, C. and VEIGA, CC. 2005. Estrutura da comunidade de macroinvertebrados associada às macrófitas aquáticas Nymphoides indica e Azolla filliculoides em dois lagos subtropicais (Rio Grande, RS, Brasil). Acta Biologica Leopondensia, vol. 27, no. 3, p. 137-145.

ALBERTONI, EF., PRELLVITZ, LJ. and PALMASILVA, C. 2007. Macroinvertebrate fauna asociated with Pistia stratiots and Nymphoides indica in subtropical lakes (south Brazil). Brazilian Journal of Biology, vol. 67, no. 3, p. 499-507. http://dx.doi. org/10.1590/S1519-69842007000300015

BARKO, JW., ADAMS, MS. and CLESCERI, NL.1986. Environmental factors and their consideration in the management of submersed aquatic vegetation - a review. Journal of Aquatic Plant Management, vol. 24, p. $1-10$.

BARROS, M. 1960. Las ciperaceas del estado de Santa Catarina. Sellowia (Herbário Barbosa Rodrigues), vol. 12, p. 181-450.

BECK, MW., HATCH, LK., VONDRACEK, B. and VALLEY, RD. 2010. Development of a macrophytebased index of biotic integrity for Minnesota lakes. Ecological Indicators, vol. 10, p. 968-979. http:// dx.doi.org/10.1016/j.ecolind.2010.02.006

BINI, LM., THOMAZ, SM., MURPHY, KJ. and CAMARGO, FM. 1999. Aquatic macrophytes distribution in relation to the water and sediment conditions in the Itaipu reservoir, Brazil. Hydrobiologia, vol. 415, p. 147-154. http://dx.doi. org/10.1023/A:1003856629837

BOLDRINI, II., LONGHI-WAGNER, HM. and BOECHAT, SC. 2005. Morfologia e Taxonomia de Gramineas Sul-Rio-Grandenses. Porto Alegre: UFRGS.
CAMARGO, AFM., PEZZATO, MM. and HENRYSILVA, GG. 2003. Fatores limitantes a produção primária de macrófitas aquáticas. In THOMAZ, SM. and BINI, LM., orgs. Ecologia e manejo de Macrófitas Aquáticas. Maringá: UEM.

CARMOUZE, JP. 1994. O Metabolismo dos Ecossistemas Aquáticos Continentais: Fundamentos Teóricos Métodos de Estudos e Analises Químicas. São Paulo: Edgard Blücher, FAPESP.

CATLING, PM., FREEDMAN, B., STEWART, C., KEREKES, JJ. and LEFKOVITCH, LP. 1986. Aquatic plants of acidic lakes in Kejimkujik National Park, Nova Scotia; floristic composition and relation to water chemistry. Canadian Journal of Botany, vol. 64, p. 724-729. http://dx.doi.org/10.1139/ b86-092

CHORUS, I. and BARTRAM, J. 1999. Water Resources. In CHORUS, I. and BARTRAM, J., eds. Toxic Cyanobacteria in Water: A guide to their Plublic Health Consequences, Monitoring and Management. New York: E \& FN Spon, Inc. vol. 1. http://dx.doi. org/10.4324/9780203478073

CIECIERSKA, H. 2006. Evaluation of the status of lakes located in the City of Olsztyn (Masurian Lake District, N-E Poland) by the macrophytoindication method (MPhI). Hydrobiologia, vol. 570, p.141-146. http://dx.doi.org/10.1007/s10750-006-0173-5

CLAYTON, J. and EDWARDS, T. 2006. Aquatic plants as environmental indicators of ecological condition in New Zealand lakes. Hydrobiologia, vol. 570, p. 147-151. http://dx.doi.org/10.1007/s10750006-0174-4

COOK, CDK. 1990. Aquatic Plant Book. The Hague: SPB Academic Publishing. 228 p.

CORDAZZO, CA. and SEELIGER, U. 1988. Guia Ilustrado da Vegetação Costeira No Extremo Sul Do Brasil. Rio Grande: Editora da FURG.

ESTEVES, FA. 1998. Fundamentos de Limnologia. Rio de Janeiro: Interciência.

FILGUEIRAS, TS., NOGUEIRA, PE., BROCHADO, AL. and GUALA., GF. 1994. Caminhamento: um método expedito para levantamentos florísticos qualitativos. Cadernos de Geociências, vol. 12, p. 39-43.

FORNO, IW. 1983. Native distribution of the Salvinia auriculata complex and keys to species identification. Aquatic Botany, vol. 17, p. 71-83. http://dx.doi. org/10.1016/0304-3770(83)90019-0

GIL, ASB and BOVE, CP. 2007. Eleocharis R.Br. (Cyperaceae) no Estado do Rio de Janeiro, Brasil. Biota Neotropica, vol. 7, no. 1, p. 163-193. http:// dx.doi.org/10.1590/S1676-06032007000100020

GUISAN, A. and ZIMMERMANN, NE. 2000. Predictive habitat distribution models in ecology. Ecological Modelling, vol. 135, p. 147-186. http:// dx.doi.org/10.1016/S0304-3800(00)00354-9

HEEGAARD, E., BIRKS, HH., GIBSON, CE., SMITH, SJ. and WOLFE-MURPHY, S. 2001. 
Species-environmental relationships of aquatic macrophytes in Northern Ireland. Aquatic Botany, vol. 70, p. 175-223. http://dx.doi.org/10.1016/ S0304-3770(01)00161-9

HEEGAARD, E., 2004. Trends in aquatic macrophyte species turnover in Northern Ireland - Which factors determine the spatial distribution of local species turnover? Global Ecology and Biogeography, vol. 13, p. 397-408. http://dx.doi.org/10.1111/j.1466822X.2004.00119.x

IRGANG, BE. and GASTAL, CVS. 1996. Macrófitas Aquáticas da Planície Costeira do RS. Porto Alegre.

JACKSON, ST. and CHARLES, DF. 1988. Aquatic macrophytes in Adirondack New York lakes: patterns of species composition in relation to environment. Canadian Journal of Botany, vol. 66, p. 1449-1460. http://dx.doi.org/10.1139/b88-199

JOYE, AD., OERTLI, B., LEHMANN, A., JUGE, R. and LACHAVANNE, JB. 2006. The prediction of macrophyte species occurrence in Swiss ponds. Hydrobiologia, vol. 570, p. 175-182. http://dx.doi. org/10.1007/s10750-006-0178-0

KOCIC, A., HENGL, T. and HORVATIC, J. 2008. Water nutrient concentrations in channels in relation to occurrence of aquatic plants: a case study in eastern Croatia. Hydrobiologia, vol. 603, p. 253-266. http:// dx.doi.org/10.1007/s10750-007-9276-x

KLEIN, AHF. 1998. Clima Regional. In SEELIGER, U., ODEBRECHT, C. and CASTELLO, JP., eds. Os Ecossistemas Costeiro e Marinho do Extremo Sul do Brasil. Rio Grande: Editora Ecoscientia. 326 p.

KRUSCHE, N., SARAIVA, JMB. and REBOITA, MS. 2002. Normais climatológicas provisórias de 1991 a 2000 para Rio Grande, RS. Rio Grande. 104 p.

MACKERETH, FJ. and TALLING, JF. 1978. Water Analysis: Some Revised Methods for limnologist. Cumbria: Freshwater Biological Association.

MADSEN, TV. and SAND-JENSEN, K. 1991. Photosynthetic carbon assimilation in aquatic macrophytes. Aquatic Botany, vol. 41, p. 5-40. http:// dx.doi.org/10.1016/0304-3770(91)90037-6

MALTCHIK, L., ROLON, AS. and GROTH, C. 2002. Diversidade de macrófitas aquáticas em área úmidas da Bacia do Rio do Sinos, Rio Grande do Sul. Pesquisas: Botânicas, vol. 52, p. 143-154.

MALTCHIK, L., ROLON, AS. and SCHOTT, P. 2007. Effects of hydrological variation on the aquatic plant community in a floodplain palustrine wetland of Southern Brasil. Limnology, vol. 8, p. 23-28. http:// dx.doi.org/10.1007/s10201-006-0192-y

MARINHO, CC., PALMA-SILVA, C., ALBERTONI, EF., TRINDADE, CRT. and ESTEVES, FA. 2009. Seasonal dynamics of methane in the water colum of two subtropical lakes differing in trophic status. Brazilian Journal of Biology, vol. 69, no. 2, p. 281-287. http://dx.doi.org/10.1590/S151969842009000200007
MENEZES, CFS., ESTEVES, FA. and ANÉSIO, AM. 1993. Influência da variação artificial do nível da água da Represa do Lobo (SP) sobre a biomassa e produção primária de Nymphoides indica (L.) O. Kuntze e Pontederia cordata L. Acta Limnologica Brasiliensia, vol. 6, p. 163-172.

MITCHELL, DS. 1974. Aquatic Vegetation and its Use and Control. Unesco.

MURPHY, KJ. 2000. Predizendo alterações em ecossistemas aquáticos continentais e áreas alagáveis: o potencial de sistemas bioindicadores funcionais utilizando macrófitas aquáticas. Boletim da Sociedade Brasileira de Limnologia, Comunicaçóes e opinióes, vol. 27, p. 07- 09 .

MURPHY, KJ. 2002. Plant communities and plant diversity in softwater lakes of Northern Europe. Aquatic Botany, vol. 73, no. 4, p. 287-324. http:// dx.doi.org/10.1016/S0304-3770(02)00028-1

NEIFF, JJ. 2000. Diversity in some tropical wetland systems of South América. In GOPAL, B. and JUNK, W., orgs. Wetlands Biodiversity. The Netherlands: Backhuys Publish. vol. 2.

NURMINEN, L. 2003. Macrophyte species composition reflecting water quality changes in adjacent water bodies of lake Hiidenvesi, SW Finland. Annales Botanici Fennici, vol. 40, p. 199-208.

PALMA-SILVA, C., ALBERTONI, EF. and ESTEVES, FA. 2002. Clear water associated with biomass and nutrient variation during the growth of a Charophyte stand after a drawdown, in a tropical coastal lagoon. Hydrobiologia, vol. 482, p. 79-87. http://dx.doi. org/10.1023/A:1021295811688

PARANHOS, R. 1996. Alguns métodos para analise da água. Rio de Janeiro: UFRJ. Cadernos didáticos.

PENNING, WE., MJELDE, M., DUDLEY, B., HELLSTEN, S., HANGANU, J., KOLADA, A., VAN DEN BERG, M., POIKANE, S., PHILLIPS, G., WILLBY, N. and ECKE, F. 2008a. Classifying aquatic macrophytes as indicators of eutrophication in European lakes. Aquatic Ecology, vol. 42, p. 237-251. http://dx.doi.org/10.1007/s10452-008-9182-y

PENNING, WE., MJELDE, M., DUDLEY, B., HELLSTEN, S., HANGANU, J., KOLADA, A., VAN DEN BERG, M., POIKANE, S., PHILLIPS, G., WILLBY, N. and ECKE, F. 2008b. Using aquatic macrophyte community indices to define the ecological status of European lakes. Aquatic Ecology, vol. 42, p. 253-264. http://dx.doi.org/10.1007/ s10452-008-9183-x

POTT, VJ. and CERVI, AC. 1999. A família Lemnaceae Gray no Pantanal (Mato Grosso e Mato Grosso do Sul). Revista Brasileira de Botânica, vol. 22, no. 2, p. 153-174. http://dx.doi.org/10.1590/S010084041999000200007

REDDY, KR. and DEBUSK, WF. 1985. Nutrient removal potential of selected aquatic macrophytes. Journal of Environmental Quality, 
vol. 14 , p. 459-462. http://dx.doi.org/10.2134/ jeq1985.00472425001400040001x

ROLON, AS., LACERDA, T., MALTCHIK, L. and IRGANG, BE. 2004. Levantamento de macrófitas aquáticas em áreas úmidas do Rio Grande do Sul, Brasil. Acta Limnologica Leopoldensia, vol. 26, no. 1, p. 17-35.

ROLON, AS., MALTCHIK, L. and GUADAGNIN, DL. 2008. Influence of area, habitat and water chemistry on richness and composition of macrophyte assemblages in shouthern Brazilian wetlands. Journal of Vegetation Science, vol. 19, p. 221-228. http:// dx.doi.org/10.3170/2008-8-18359

ROLON, AS., HOMEM, FR. and MALTCHIK, L. 2010. Aquatic macrophytes in natural and managed wetlands of Rio Grande do Sul State, Southern Brazil. Acta Limnologica Brasiliensia, vol. 22, no. 2, p. 133-146.

RØRSLETT, B. 1991. Principal determinants of aquatic macrophyte richness in northern European lakes. Aquatic Botany, vol. 9, p. 173-193. http://dx.doi. org/10.1016/0304-3770(91)90031-Y

SCHEFFER, M. 1998. Ecology of Shallow lakes. London: Chapman \& Hall.

SØNDERGAARD, M., JOHANSSON, LS., LAURIDSEN, TL., JØRGENSEN, TB., LIBORIUSSEN, L. and JEPPESEN, E. 2010. Submerged macrophytes as indicators of the ecological quality of lakes. Freshwater Biology, vol. 55, no. 893-908.

SPENCE, DHN. and MABERLY, SC. 1985. Occurrence and ecological importance of $\mathrm{HCO}_{3}$ use among aquatic higher plants. In LUCAS, WJ. and BERRY, JA., eds. Inorganic Carbon Uptake by Aquatic Photosynthetic Organism. Maryland: The American Society of Plant Physiologists.

SPONCHIADO, M. and SCHWARZBOLD, A. 2008. Influência da macrófita aquática Luziola peruviana na dinâmica de um ecossistema de açude raso. In Anais do Seminário de Estudos Limnológicos em Clima Subtropical, 2008. Rio. Grande. 6 p.

TER BRAAK, CJF. 1986. Canonical Correspondence Analysis: a new eightvector technique for multivariate direct gradient analysis. Ecology, vol. 67, p. 1167-1179. http://dx.doi.org/10.2307/1938672

THOMAZ, SM. 2002. Fatores ecológicos associados à colonizaçáo e ao desenvolvimento de macrófitas aquáticas e desafios de manejo. Planta Daninha, vol. 20, p. 21-33.

THOMAZ, SM. and BINI, LM. 1998. Ecologia e manejo de macrófitas aquática em reservatórios. Acta Limnologica Brasiliensia, vol. 10, no. 1, p. 103-116.

THOMAZ, SM., SOUZA, DC. and BINI, LM. 2003. Species richness and beta diversity of aquatic macrophytes in a large subtropical reservoir (Itaipu Reservoir, Brazil): the limnology and morphometry. Hydrobiologia, vol. 505, p. 119-128. http://dx.doi. org/10.1023/B:HYDR.0000007300.78143.e1

TRINDADE, CRT. 2008. Biomassa, produtividade e nutrientes de Salvinia herzogii de la Sota e Azolla filiculoides Lam., em dois corpos d'água rasos subtropicais (Rio grande, RS-Brasil). Rio Grande: Universidade Federal do Rio Grande. [Dissertação de Mestrado em Biologia de Ambientes Aquáticos Continentais].

TRINDADE, CRT., FURLANETTO, LM. and PALMA-SILVA, C. 2009. Nycthemeral cycles and seasonal variation of limnological factors of a subtropical shallow lake (Rio Grande, RS, Brazil). Acta Limnologica Brasilensia, vol. 21, no. 1, p. 35-44.

TRYON, RM. and TRYON, AF. 1982. Ferns and allied plants with special reference to tropical America. New York: Springer Verlag. 857 p.

TOIVONEN, H. and HUTTUNEN, P. 1995. Aquatic macrophytes and gradients in 57 small lakes in southern Finland. Aquatic Botany, vol. 51, p. 197-221. http://dx.doi.org/10.1016/03043770(95)00458-C

VALDERRAMA, JC. 1981. The simultaneous analysis of total nitrogen and phosphorus in natural waters. Marine Chemistry, vol. 10, p. 109-122. http://dx.doi. org/10.1016/0304-4203(81)90027-X

VAN-DE-HOECK, C., MANN, DG. and JANHS, HM. 1995. Algae an introduction to phycology. Cambridge: university of Cambridge Press. 627 p.

VAN GEEST, G. 2005. Macrophyte succession in floodplain lakes. Spatio-temporal patterns in relation to hydrology, lake morphology and management. The Netherlands: Wageningen University. [Dissertation].

VESTERGAARD, O. and SAND-JENSEN, K. 2000 Alkalinity and trophic state regulate aquatic plant distribution in Danish lakes. Aquatic Botany, vol. 67, p. 85-107. http://dx.doi.org/10.1016/S03043770(00)00086-3

VIEIRA, EF. and RANGEL, SRS. 1988. Planície Costeira do Rio Grande do Sul: Geografia Física, Vegetaçáo e Dinâmica Sócio-Demográfica. Porto Alegre: Sagra.

VIROLA, T., KAITALA, V., LAMMI, A., SIIKAMÄKI, P. and SUHONEN, J. 2001.Geographical patterns of species turnover in aquatic plant communities. Freshwater Biology, vol. 46, p. 207-264. http://dx.doi. org/10.1046/j.1365-2427.2001.00767.x

WETZEL, RG. 1990. Land-Water Interfaces: Metabolic and Limnological Regulators. Verhandlungen Internationalen der Vereinigung Theoretische peles und Limnologie Angewandte, vol. 24, p. 6-24.

WETZEL, RG. 1993. Limnología. Lisboa: Fundação Calouste Gulbenkian. 